\title{
Aldo Rossi: the 'autobiography' and its fragments
}

\author{
Antonello Marotta*
}

\begin{abstract}
The year 1966 demarcated a borderline in the urban design discipline. Three books published that indicated a change of direction: City architecture by Aldo Rossi, The territory of architecture by Vittorio Gregotti and Complexity and contradiction in architecture by Robert Venturi. Aldo Rossi, in contact with Ernesto Nathan Rogers and "Casabella-Continuità", shifted the attention to the historic, consolidated city, the monument and urban rules of archaeological fabric, while Vittorio Gregotti developed a research trend that founded architecture on geography. Finally, Robert Venturi opened up the architectural project, revealing its relations with media culture and with the contradictions of the consumer society. Critical essays investigated the phase following the second half of the Sixties, at the time when Aldo Rossi began, in 1976, to travel across America, invited by the Institute for Architecture and Urban Studies to show his works at a series of exhibitions. His book A Scientific Autobiography, written and developed in America, belonged to this phase, which characterised at an international level by the birth of Paper Architecture (the movement that had placed design at the centre of reflection as the expression of new spatial poetics). The essay aimed to show a change in the paradigm of Rossi's thought, no longer and solely focusing on past and physical architecture, but unrelentingly entwined with the individual and personal destiny of the Milanese architect. Memory became an active, live field of investigation, as Rafael Moneo maintains on Rossi's thought, in which an objective vision of architecture no longer counted but one that included the subject and his fragments.
\end{abstract}

Keywords: Paper architecture, Drawings, City, Memory, Theater

\section{Memory machines}

A great deal has written about Aldo Rossi: books, essays, treatises on his thought and yet, fundamentally, his strength is that he cannot include in any category. I met Aldo Rossi in the Nineties, on the occasion of a conference he held in Naples. That day his being outside all contexts emerged; the architect often repeated the words malgré moi (despite myself). He liked to use that expression (I was an architect despite myself. I could have done something else). It was a way of playing down his importance though drew attention to his role of thinker, poet and shaman, consequently elevating him to a dimension indescribable. At the end of the conference, I had approached him, as many students did, fascinated by

\footnotetext{
*Correspondence: amarotta@uniss.it

Department of Architecture, Design \& Urban Planning, University

of Sassari, Palazzo del Pou Salit-Piazza Duomo 6, 07041 Alghero, Sassari, Italy
}

by Alberto Ferlenga: Aldo Rossi, Deutsches Historisches Museum, Berlino (Electa, Milan 1990).

I asked Rossi for some document to remember that meeting by, as I sometimes asked architects and masters that I respected-a sign, a small sketch for future memory. I wanted a memento to keep. Rossi drew a small square one centimetre by one, a recognisable sign of his style, like the windows/openings that would rule over his stylistic code (the San Cataldo Cemetery of Modena of 1971-1978 comes to mind), and above it his well-known stylised signature.

I opened that book again while immersed in these reflections.

The Deutsches Historisches Museum, never built, remains, in my opinion, one of the most exciting works of his production. It often happens that particular research finds a field of greater strength precisely because it remains unexpressed-signs and utopias that stay on 
paper. It was a work that condensed Rossi's research, made up of urban memories, with the city at the centre of his critical, reconstructive gaze, but also of fragments of desired places, small gestures, in an analogical course.

Rossi much impressed me: I expected to find a more rigid person, more overbearing and self-confident; we often remain unmoved in our interpretations, looking at works of testimonies written. I found a cultured, refined man with an extremely persuasive voice, confidential, at times disarming and perhaps disarmed. His story of the conference offered more openings than answers.

His book The architecture of the city, published in 1966, had brought him extraordinary international fame in the years that followed. It gathered together texts and research carried out previously, in 1960, as he recalled, with reflections developed around the figure of Ernesto Nathan Rogers and his review "Casabella-Continuità". He collaborated with the review from 1955 and wrote for it from 1961 to 1964, the last year in which Rogers was its director. In that workshop, authoritative architects and theorists of the calibre of Vittorio Gregotti, Carlo Aymonino, Marco Zanuso and Francesco Tentori had trained.

The book had conditioned international culture, refounding over time a right sector of Europe and reaching America. A book's fortune is linked historically to its own time, both geographic and mental, and in this case, it had placed urban studies once more in the operative field of the architect: a European city, historical in his structure.

In the same year (1966) Vittorio Gregotti published The territory of architecture and Robert Venturi Complexity and contradiction in architecture. A crucial year in which themes were put forward, in particular concerning history, geography, the media. The latter, handled by Venturi, was to change disciplinary arguments in the coming years.

In 1976 Aldo Rossi undertook a different journey, to America, which would lead him to consider new aspects of the discipline in a social and cultural urban context different from the Vienna of Loos or the Marxist Soviet Union.

His stay in America was decisive. In 1976 he accepted an invitation from the Institute for Architecture and Urban Studies. Displays of his work appeared, and conferences held at various institutions, such as the Cornell University School of Architecture in Ithaca (NY), Cooper Union of New York, and the University of California in Los Angeles.

In the years from 1977 to 1979 Rossi was still in America, meeting and comparing notes with significant architects like Oswald Mathias Ungers, and effectively strengthening his collaboration with the Institute for
Architecture and Urban Studies. These were critical years in which Rossi developed open, intricate drawings and projects full of possibilities.

Rafael Moneo succeeded in shrewdly understanding this phase in his text Theoretical anxiety and design strategy in the work of eight contemporary architects. $\mathrm{He}$ maintained that in America Rossi became aware that his drawings were his real work.

It was a risky assertion, but not without foundation. Drawing, in Rossi, Moneo maintained substituted architecture.

The Spanish architect interpreted the change from an idealistic system founded on the rational principles of city construction, summarised in his book-manifesto, to a phase in which the only iconography remains alive. Within this rupture of sense, he read the opening up of new fields of investigation, more private and personal.

\section{Paper architecture}

In America, in those same years, a revolution was taking place linked with the theses expressed by Charles Jencks in the book The Language of Post-Modern Architecture. The battle with the ideals of modernity and abstraction brought the focus back on figuration. A patrimony of classical quotations, a new relationship with the city of the past and its places. Meanwhile, in 1978 Colin Rowe and Fred Koetter were proposing a city made up of parts, with their famous Collage City, fragmented like in a collage, but able to be recomposed in a unitary whole.

Rossi was attracted by this new transformation, into a different urban, cultural context from the European city, but his contribution led outwards, beyond the confines of the frame.

Parallel to his American visits, his drawings of the 1976-1979 phase charged with new values. However, this dimension, basically this discomfort, was anticipated in drawings like Architecture assassinated (1974) and Cedimenti terrestri (1977).

Here architecture enters a tragic phase, reviving a theatre of life and death. In Cedimenti terrestri this disintegration of architecture has the skyscrapers of New York as a background.

It was a course in which the analogous, the fragment and the stage reconstructed an extraordinary Theatre of memory, following a route along which we can list the drawings made in those years: The analogous city (1976), Urban fragments in New York (1977), The window of the poet in New York with the hand of the Saint (1978), Other conversations (1978), up to those for the Scientific Theatre (1978) and the Theatre of the World (1979).

In these drawings, windows originated which opened up spaces to memory, layers, parallel gazes, archaeological recollections. The interpretation of Rossi's drawings 
has often aimed at understanding work when, in fact, it opens up other fields of investigation. The territory of drawing is not linear, on the contrary, the memory has ramifications, and often the compositions accumulate matter and memories.

The drawing appears in this phase to be a field parallel to work, certainly able to reveal it but, at the same time, to create an area of investigation, of inquiry, like a place that has its own life. At an international level, a new movement was born. Ideas, formulation and programmatic texts that did not have the materialisation of physical work reconstruct a field of the 'possible'.

A phase in which the drawing lived alongside the work, triggering dynamics that did not stay on the paper but generated new literature over time.

Paper Architecture would also witness, apart from Rossi's drawings quoted, including The analogous city (1976), contributions by Rem Koolhaas and Elia Zenghelis, with the work Exodus, or the Voluntary Prisoners of Architecture (1972): a model of the global consumer city, utopian and linear, superimposed without mediation on the regular plan of New York, and those by Peter Eisenman, like House VI, Cube Transformation Studies (1976), on the Terragni grid exercises.

Bernard Tschumi's production was of particular interest, with the drawing Episode 4: The Block from The Manhattan Transcripts (1976-1981), in which the architect developed his early experiments with linguistic deconstruction, followed by Daniel Libeskind's Micromégas (1978), drawings on which we will dwell.

If we do not enter into this vision, we will not understand the influence Rossi had on figures different from himself: I am thinking indeed of the production of Daniel Libeskind, who began his most famous drawings in 1978: the Micromégas. These recalled the tale of the same name, Micromégas, by Voltaire in 1752, telling of an alien chased away by the scientific community of his planet on a course driven by his curiosity, by discovery and imagination, in a region without boundaries. They are labyrinthine compositions, made of lines and trajectories, which generate useless machines in stratification of possible tracks. The critics put Libeskind against Rossi for years, through categorial readings and substantial syntactic differences. In fact, there was great respect between the two.

Libeskind wrote about Rossi's Theatre of the World and Camillo's Theatre of Memory in 1980 in the article published in Oppositions: Deux ex Machina/Machina ex Deo. Comparing the two-stage systems, he pointed out Rossi's interpretation of the theatre:

"a "machine" or apparatus, the purpose of which depends on a secret message-a message that finds its echo in the place and the enslaved mind of the spec- tator. Its ultimate aim is not to "show" reality but reveal a new kind through a different pattern [...] In this way the "theatre" hopes to go back to guiding the will of man by showing him an image capable of reconstructing memory itself, memory in which time ceases to be the colourless instrument of events and becomes inseparable from their content" (Libeskind 1982).

Libeskind, in contact with Rossi, worked on his most intense, deep-reaching research: let us remember that the American architect opened his studio Architecture intermundium in Milan in 1986, on the occasion of the Triennial in which he took part.

However, the invitation to Rossi to take part in the Venice Biennial of 1985 on the theme of the fortified city of Palmanova was fundamental. On that occasion, Libeskind produced three machines, three mnemonic devices: the reading machine, the memory machine and the writing machine.

To be specific, the Writing machine was a model that generated thought: there were 49 devices, composed of 2662 components, able, as in an Orphean system, to generate infinite combinations of words and thoughts. This machine, composed of 7 rows by 7 , together with the Line of Fire, the installation created in 1987 after the Biennial, pre-empted the project for the Jewish Museum in Berlin (1989-1998): suffice it to contemplate both the fragmented plan and the Garden of Exile, formed by 49 sloping columns with olive trees, the symbol of life, on their summits. This garden invoked the Palmanova Writing machine, indeed.

I believe Rossi fervently created mental devices and I think that Libeskind, without his experience of the Biennial and in Milan, would not have been able to create his work-manifesto of the Holocaust Museum.

\section{Fragments of thought}

However, let us go back to the drawings and try to understand the unresolved node of Aldo Rossi's Scientific Autobiography.Rafael Moneo offers us some clues as regards the American period:

"[...] Rossi realised he was a master of his sentiments more than of the instrumentalisation of knowledge, as he had claimed at the beginning of his career; that he was more capable of constructing what he felt, than of establishing that series of linking rings that led in a hierarchical way from the type to the monument. In actual fact, Rossi began to work on a new book in the United States, A Scientific Autobiography, in which the leap we are talking of clearly came about, leading from knowledge to sentiment. If the early Rossi tried, 
above all, to be objective, the Rossi that returned from the United States was convinced that he could speak only of himself, that it was the subject that counted" (Moneo 2005, p. 108-109).

A Scientific Autobiography was published for the first time in the United States in 1981 (for the Institute for Architecture and Urban Studies, The Mit Press, Cambridge 1981) and in various languages, from Spanish to Japanese, before being edited for the first time in Italy in 1990 by the publishers Pratiche Editrice of Parma, and reprinted by the Nuova Pratiche Editrice in 1999, 2 years after Rossi's death. Nine years passed between the American version and the Italian one, a vast period, almost a 'removal.' We must note this cultural gap, with such an extended length of time. It seems that Italian culture was not ready to cope with Rossi's new book, which would lead towards other readings, especially abroad.

In 1990, the year of publication in Italy of $A$ Scientific Autobiography, the Milanese architect was awarded the prestigious Pritzker Prize. Issue No. 12 of Zodiac (September 1994/February 1995), directed by Guido Canella, retraced the prestigious awards given over the years to famous architects, from Philip Johnson in 1979 up to the one given to Fuminiko Maki in 1993.

This issue of the review opened with a dedication to Manfredo Tafuri, who had died a year earlier.

It followed a double track, between the loss of a great historian and the celebration of an architect at the apex of his design work on the projects he was creating throughout the world, from Berlin to Fukuoka.

Aldo Rossi was to die a few years later, tragically in 1997, following a car accident. In his speech accepting the Pritzker award, Rossi subdued the souls, ever taking the in spite of myself position: "I feel, in some way, like a student about to sit for an exam. A moment's concentration, a guilty feeling and, suddenly, the showdown" (Rossi 1995, p. 193).

A Scientific Autobiography did not have the same fortune in Italy as The architecture of the city, for reasons of a historic nature, whereas it fuelled the debate abroad profoundly.

As the author recalled at the beginning of his trip, the book gathered together the notes of some 10 years, which completed so that they would not become memories.

It impresses me that Rossi wrote his autobiography still as a young man; being born in 1931, in 1981 he was 50. It is like weighing up one's life while still in the heart of it.

There is not a vast distance between The architecture of the city and A Scientific Autobiography. However, they record two periods that were historically and existentially very different: the Sixties, when, in contact with Ernesto Rogers, the discipline of the modern movement was to be re-founded, and the Eighties, when parallel to the birth of the Postmodern, modernity was a period to be dissolved and crushed.

\section{"The beautiful illusion of the modern movement, calm and moderate, had crumbled under the rough but concrete collapse of the bombs" (Rossi 2005, p. 118).}

Rossi vigorously proclaimed a new vision, which incorporated time and life, dramatically uniting them:
"The dual sense of time, atmospheric and chrono- logical, dominates every construction; this dual sense of energy is what I now see clearly in archi- tecture, just as I might see it in other technical subjects or arts. In my first book, The architecture of the city, I identified this same problem with the relationship between form and function; form both presided over the construction and endured, in a world where functions were changing continuously and inform material was changing. The material of a bell is transformed into a cannon ball; the form of an amphitheatre into that of a city; the form of a city into a palace. Written around the age of thirty, this book seemed final to me, and still today his statements have not been sufficiently developed. Later it seemed clear to me that the work needed to be included in even more complex motivations, above all through the analogies that intersect our every single action. Ever since my early projects, where I was interested in Purism, I have loved con- taminations, small changes, comments and repeti- tions" (Rossi 2005, p. 8).

This is a Rossi different from the one of The architecture of the city, written when he was not yet thirty, where: "I despised memories and at the same time made use of urban impressions, seeking immobile laws of a typology without time behind the sentiments" (Rossi 2005, p. 25).

A portrait of the Milanese architect emerges that is homely, subjective and less rigid. The part of Rossi's thought still alive and strong is, in my opinion, contained in his drawings, in those corners dead and alive of his meditation, made up of co-presences, leaps, ramified conditions, in that dilation of thought.

Nowadays, his poetics may be born again through his drawings of the Seventies that created open spaces where the multitude of his reflections emerged with greater richness. The Autobiography crystallizes this pathway and draws attention to the space underlying it, the one where memory re-emerges as an interpretative field. 
"It seems to me sufficient by now to fix our attention on objects, understand them, propose them again; rationalism is necessary, as is order, but any kind of order may be overturned by external facts of a historic, geological or psychological origin. The season of architecture was no longer in its dual nature of light and shade or aging of things but it came forward as devastated time that picks things up again. All this led me to the concept of identity. And the loss of identity. Identity is something unique, typical, but it is also a choice. In my drawings Architecture assassinated and Elba cabins I tried to express these relationships" (Rossi 2005, p. 27).

This is the Rossi that asks us new questions, rather than close the circle, and it is the man of the conference who is relaunching - the party still able to offer new ideas.

What indicated along this route was no longer so much, or only, the definition of rules, but a widerranging idea, where indeed the theatre re-emerged, the mediocre actor and the sublime one. Measurement, the wooden yardstick of builders that for Rossi was the instrument and apparatus of architecture, in fact, needed something else, like when he talks about his studies for Prof. Golinellis's Topography exam at Milan Polytechnic. The measurements taken of Piazza Leonardo da Vinci were never univocal; the triangulations often did not close. Here he found the broader sense of the project, of a space that, being imprecise, left an opening for new dimensions of space.

I believe Rossi's world, tragic and linked with the drama of life, found a high safety valve in his drawings. At this point, his work became more incisive as his theory reopened and knitted the links back together of various pasts, memories, myths and mythology.

"For a few years it has been easier for me to draw or rather use the sort of handwriting that is a cross between drawing and writing" (Rossi 2005, p. 72).

Rossi recalls the Project for a villa with interior, drawn in the autumn of 1978. "Actually this project, like these notes, speaks of the break-up of the discipline" (Rossi 2005p. 73).

What was he looking for along those 'American' pathways and the Scientific Autobiography? Without doubt, the theatre and the stage on which man, architecture and the city could converse.

It is not by chance that the work that gave him his place in history was his Theatre of the world of 1979, in which the themes handled condensed, and where architecture, construction, rationality, history, the theatre, the immaterial, the symbol, matter, resistance, iconicity and dissolution condensed in the image of the work travelling on a barge in the Venetian lagoon, under an embittered sky.
"My love of the Venetian Theatre was also this; it being an anomalous work and presenting itself with the same grandeur and fragility of a machine" (Rossi 2005, p. 104-105). This machine, he was to say later, was the time machine.

Rossi was attracted in this phase by the irrational and the uncertain, but he distrusted those who avoided organisation: "Because only this organisation allows hitches, variations, joys and disappointments" (Rossi 2005, p. 82).

It is a text in which the theme of death returns persistently, of desire as a loss, of memory as disappearance. The emblematic cases of Leon Battista Alberti's Sant'Andrea of Mantova and the Tempio Malatestiano in Rimini return as a representation of Time, but also of the non-finite, of space that opens up again.

It is evident, as has already been consolidated that this derives from the melancholic thought of De Chirico's Metaphysics, which gently deforms the city, with shadows and expectation. But with the Autobiography he calls to mind rather than the metaphysical city. The self-portrait of De Chirico of 1924, in which the relation between life and death ambiguously described. Almost in a state of hibernation, it is only the face that is alive, while the trunk and hands are as if frozen. In Rossi the theme of death is urgent, like an innermost desire, a liberation, and atonement.

The city enters the pathways of life. Not by chance does he quote two central figures: if the previous phase marked by De Chirico's and Sironi's paintings, now it is in the sculptures of Giacometti and Beckett's texts that the existential sense of those years found.

"I loved the Pantheon's subsidence described in the books on statics; the unexpected crack, a visible but contained collapse, gives enormous strength to architecture because its beauty could not be foreseen" (Rossi 2005, p. 47).

Memories, subsidence, deformations, lines that cross each other recalled.

A phrase by Hemingway quoted; he defines it as dreadful yet fascinating: "All things truly wicked start from an innocence" (Rossi 2005, p. 87).

What had been an all-time enemy emerged as a space of reflection: "[...] rationality or a minimum of lucidity enabled the most fascinating aspect to be analysed with certainty: the irrational and the inexpressible" (Rossi 2005, p. 74).

Rossi clarified his interest in immunology books, specifically Essential immunology by Ivan Roitt. "A specific moment does not exist without memory, nor does a memory that does not come from a specific moment; and only this union enables the knowledge of one's own individuality and the contrary" (Rossi 2005, p. 88). 
This perspective linked with pathology indeed shows fractures.

"I love the beginning and end of things: but perhaps, above all, things that break and are reassembled, archaeological operations and surgical ones. Many times during the course of my life I have been to hospital for fractures or other accidents to my bones and this has given me a sense and knowledge of the engineering of the body that was otherwise unimaginable" (Rossi 2005, p. 117).

This fracture ruptures the one-to-one relationship with memory.

A passage from the Autobiography that I give below on the theme of translation is fascinating. It is not the tradition-translation-betrayal node, but a different space.

"Before finishing with this issue (Rossi is talking about the Hölderlin translation, [author's note]) some texts have been fundamental for me that were, let us say, of an architectural nature; I must mention the translation of Etienne Louis Boullee and the introduction to this text. I was told, and I consider it a compliment, that this translation is not very faithful or that, at least, it is an invention. I admit that it is certainly a shared work, also because Boullée's French is by no means easy to translate and moreover I found in him a harmony that I have perhaps never experienced again. It was a work of 1967 and when I began it I was around 35 years of age, so it cannot be considered a work of my youth. I believe I wrote it in Santa Margherita Ligure in a house by the sea, helped by Sonja and my little son: I sometimes think how works like this accompany particular periods of life and how I was able, in this situation, to identify with an old French scholar, but I was struck by the phrase in which Baudelaire stated that "correspondances" exist" (Rossi 2005, p. 65-66).

Boullée is a complex figure, read by many as utopian, and by others as the founder of Positive and rational ideas. However, Rossi inquires into Boullée's text, in this passage from conventional rationalism to exalted rationalism. Going beyond the French architect's reflections, he places him in the present time and colours him with a biography. He exalts the reflection where Boullée defined its outlines. Rossi spoke of aspects that could not fixed, that evaded staticity, a secret, wonderful story.

Our processes are everything but scientific, they never give an exact sum but are, on the contrary, the manifestation of our perspective, which must necessarily be personal, private, indeed autobiographical.

Acknowledgements

Not applicable.

Authors' contributions

The author read and approved the final manuscript.

Funding

Not applicable.

Availability of data and materials

Not applicable

Ethics approval and consent to participate

Not applicable.

Consent for publication

Not applicable.

Competing interests

The author declares no competing interests.

Received: 23 July 2018 Accepted: 25 November 2019

Published online: 05 December 2019

\footnotetext{
References

Libeskind D (1982) Deus ex Machina Machina ex Deo. In: Prandi A (ed) Brusatin M. Aldo Rossi. Teatro del Mondo. Cluva Libreria Editrice, Venice

Moneo R (2005) Inquietudine teorica e strategia progettuale nell'opera di otto architetti contemporanei. Electa, Milan

Rossi A (1995) Discorso di accettazione. In: Zodiac 12, September 1994-February 1995

Rossi A (2005) Autobiografia scientifica. Nuova Pratiche Editrice, Milan
}

\section{Publisher's Note}

Springer Nature remains neutral with regard to jurisdictional claims in published maps and institutional affiliations. 